\title{
COMMENTARY
}

\section{The comparative endocrinology of appetite}

Open any recent copy of the Journal of Endocrinology and you will see immediately that, compared with a decade ago, endocrinology has gained a new interest - that of appetite regulation. Obesity has now reached epidemic proportions in the developed world, but it was not until the discovery of leptin in 1994, that the modern endocrinology of appetite regulation and energy expenditure began (Zhang et al. 1994). Since then, enormous advances have been made, many of which have been reviewed in an outstanding recent Starling review of this subject (Wynne et al. 2005).

The majority of the published work in this new field, reasonably enough, relates to mice and men. However, related control mechanisms exist in other species and clearly there may be important insights to be gained from their study. For this reason, the journal, through the Society for Endocrinology, was enthusiastic about publishing papers from a symposium on the 'Endocrinology of Feeding and Nutrition' at the recent Conference of European Comparative Endocrinologists in Manchester, UK. In this and forthcoming issues, we shall be publishing three review articles based on presentations at this symposium that serve to illustrate this point. In this issue Bechtold \& Luckman review the role of RFamide peptides in feeding. This extensive class of peptides is used by vertebrates and invertebrates for a range of purposes including the regulation of feeding behaviour. Future issues will feature articles on feeding behaviour and the role of the hugin circuit in Drosophila by Melcher et al. and a novel mammalian model of seasonal leptin resistance by Król \& Speakman. Ultimately, it is to be hoped that integration and development of these scientific areas will enhance our understanding of the physiology of energy homeostasis and identify new mechanisms whereby body weight is normally regulated.

$J R$ E Davis, Editor-in Chief A J L Clark, Deputy Editor

\section{References}

Wynne K, Stanley S, McGowan B \& Bloom SR 2005 Appetite control. Journal of Endocrinology 184 291-318. Zhang Y, Proenca R, Maffei M, Barone M, Leopold L \& Friedman JM 1994 Positional cloning of the mouse obese gene and its human homologue. Nature 372 425-432. 